\title{
Research on the Influencing Factors of Enterprise Environmental Information Disclosure--An Example of Petrochemical Listed Companies
}

\author{
Yinling Liu ${ }^{1, a^{*}}$ and Yang $\mathrm{Gao}^{2, \mathrm{~b}}$ \\ ${ }^{1}$ School of Management, Yulin University, China,719000 \\ ${ }^{2}$ Career Technical College Yulin, China,719000 \\ a263050607@qq.com, ${ }^{\text {b } 3068928155 @ q q . c o m ~}$
}

Keywords: Environmental information disclosure; Influence factors; Petrochemical enterprises

\begin{abstract}
Environmental problem has become the focus of global concern, and protecting the environment has become common aspiration of enterprises and individuals. In recent years, the awareness of environmental protection of various enterprises has been improved, mainly manifested in the disclosure of environmental information. However, because our country has not yet issued the relevant guidelines for enterprise reference system, the environment information disclosure content of each enterprise is different, the quality is uneven. In order to make the environmental information disclosed by enterprises play a substantive role, it is necessary to analyze the influencing factors of environmental information disclosure. This paper adopts empirical research method, based on the Shanghai Petrochemical listed companies as a sample, to the level of corporate environmental information disclosure as the dependent variable, the company scale, profitability, capital structure and other 11 factors as independent variables, by constructing a model to study the correlation between the selected factors and enterprise environmental information disclosure and significant.
\end{abstract}

\section{Introduction}

With the continuous progress of economic globalization, the material life of mankind has been greatly improved, and the rapid development of science and technology has added a lot of color to our life. It seems that mankind is moving towards a better future. But the ensuing environmental problems have broken the long cherished wish of human beings, the consumption of various ecological resources and the wanton discharge of large amounts of pollutants pose a great threat to the living environment of mankind. All this "Mastermind" is the enterprise, especially the heavy polluting enterprises. Therefore, enterprises should take responsibility to improve the pollution and protect the environment. Due to various reasons, the disclosure of environmental information is not optimistic in China. Therefore, it is imperative to improve the current situation of enterprise environmental information disclosure in China. In this context, it is urgent to strengthen the study of environmental information disclosure of enterprises in China.

\section{Empirical Analysis}

Sample Selection. The choice of petrochemical enterprises of heavy pollution such as the object of study, in 2016, Shanghai A shares 50 listed petrochemical enterprises, excluding the ST enterprises, to suspend the listing of PT enterprise and data incomplete information of the enterprise, eventually identified 30 companies as the sample[1].

Variable Setting Dependent Variable.

This paper studies the effect of independent variables of the selection of variables, which refers to the most scholars selected EDI to reflect the corporate environmental information disclosure level1].Based on the nature of corporate environmental information disclosure was evaluated, including assignment to quantitative disclosure of 3 assignment qualitative disclosure 2 general disclosure Assignment 1, did not disclose the assignment 0 .

Argument. $\mathbf{X}_{1}$ company scale: the total assets are often used to measure the size of the enterprise, so the paper also selects the natural logarithm of the total assets at the end of the year to represent the scale of the enterprise[2]. 
$\mathbf{X}_{2}$,Profitability: the most commonly used indicator of corporate profitability is the return on net assets. Therefore, this paper chooses the ratio to measure the profitability of Sample Firms[1].

$\mathbf{X}_{3}$,Capital structure: capital structure usually reflects the proportion of corporate liabilities and owner's equity. The capital structure of Sample Firms is expressed in terms of its liabilities.

$\mathbf{X}_{4}$, The proportion of independent directors: the degree of independence of Sample Firms in the article is measured by the proportion of the independent directors in the listed companies.

$\mathbf{X}_{5}$,one person concurrently: whether the company's ownership and management rights are separated is the direct embodiment of the company's leading body. The article reflects the leadership structure of the board of directors of Sample Firms with the two rights as one person[1]. This variable is used as dummy variable, that is, when the Sample Firms appears, one person concurrently holds the value of 1 , otherwise it is 0 ;

$\mathbf{X}_{6}$, the proportion of the first shareholder: the shareholding ratio of the first shareholder's voting decision determines the enterprise ownership, so the factors that can reflect the enterprise's ownership status.

$\mathbf{X}_{7}$, the proportion of tradable shares: the higher proportion of tradable shares in the total shares of listed companies, the more able to reflect the true value of the enterprise. Therefore, the true level of the proportion of tradable shares can measure the enterprise environmental information disclosure.

$\mathbf{X}_{8}$, the government's investment in environmental protection: the use of Sample Firms' provinces and autonomous regions, the natural logarithm of the total amount in the government within one year of investment in environmental governance as an alternative variable.

$X_{9}$, the size of an accounting firm employed by an enterprise: the size of an accounting firm can reflect the credibility and admissibility of the audit opinion. The article takes it as dummy variable, when the comprehensive ranking of accounting firms employed by Sample Firms ranks first ten, the value is 1 , otherwise it is $0[1]$.

$\mathbf{X}_{10}$, is it state-owned: The state-owned enterprises will be divided into state-owned and non state-owned, values were 1 and 0 .

$\mathrm{X}_{11}$, the economic development region of an enterprise: GDP is usually used to measure the level of economic development. The article takes it as dummy variable, when Sample Firms's economic development region per capita GDP is higher than the national average level, the value is 1 , otherwise the value is 0 .

Model Building. Based on the selection of Sample Firms and the setting of independent variables and dependent variables, this paper constructs a multiple linear regression model:

$$
\mathrm{Y}=\beta_{0}+\beta_{1} \mathrm{X}_{1}+\beta_{2} \mathrm{X}_{2}+\beta_{3} \mathrm{X}_{3}+\beta_{4} \mathrm{X}_{4}+\beta_{5} \mathrm{X}_{5}+\beta_{6} \mathrm{X}_{6}+\beta_{7} \mathrm{X}_{7}+\beta_{8} \mathrm{X}_{8}+\beta_{9} \mathrm{X}_{9}+\beta_{10} \mathrm{X}_{10}+\beta_{11} \mathrm{X}_{11}
$$

Statistical Analysis. The descriptive statistical analysis and regression analysis of the sample data by EXCEL software, to determine the independent variables and the dependent relationship between variables, and the conclusion of the disclosure of environmental information according to put forward the corresponding improvement suggestions.

Descriptive Statistics. Table 1 shows, in all Sample Firms, $\mathrm{X}_{4}$ a person holding the proportion is $13.33 \%$, only a few samples that Chairman and general manager of the enterprise there was a parttime, so as to avoid a large area of the rights of the phenomenon of concentration; the average $\mathrm{X}_{9}$ is 0.5667, the ratio of examples of comprehensive ranking of accounting firms more than half of the Sample Firms hired are among the top ten, this shows that the credibility of the audit opinion are higher; the average number of $\mathrm{X}_{10}$ was 0.4667 , that nearly half of the Sample Firms company belongs to state-owned enterprises, is conducive to enhance the enthusiasm of enterprise environmental information disclosure; the $X_{11}$ value is 0.70 , that mean per capita GDP $70 \%$ the Sample Firms at the regional economic development is higher than the national average of. $\mathrm{X}_{7}$ was 0.3802 , the average overall equity is relatively concentrated in. $\mathrm{X}_{6}$ was 0.4582 , indicating the total number of shares in Sample Firms , The proportion of circulation shares is less than 50\%; The average number of $\mathrm{X}_{5}$ is 0.2240 , which shows that the proportion of independent directors in Sample Firms is relatively low. 
Table 1 descriptive statistical analysis

\begin{tabular}{|l|l|l|l|l|}
\hline argument & least value & crest value & average & standard deviation \\
\hline$X_{1}$ & 8.71 & 12.16 & 9.8703 & 0.6270 \\
\hline$X_{2}$ & -1.7871 & 0.465 & -0.0376 & 0.3634 \\
\hline$X_{3}$ & 0.191 & 0.978 & 0.5102 & 0.2133 \\
\hline$X_{4}$ & 0 & 1 & 0.1333 & 0.3457 \\
\hline$X_{5}$ & 0.1364 & 1.125 & 0.2240 & 0.1762 \\
\hline$X_{6}$ & 0.188 & 0.9424 & 0.4582 & 0.1573 \\
\hline$X_{7}$ & 0.1198 & 0.923 & 0.3802 & 0.1841 \\
\hline$X_{8}$ & 1.23 & 2.38 & 1.833 & 0.2925 \\
\hline$X_{9}$ & 0 & 1 & 0.5667 & 0.5040 \\
\hline$X_{10}$ & 0 & 1 & 0.4667 & 0.0926 \\
\hline$X_{11}$ & 0 & 1 & 0.70 & 0.4661 \\
\hline
\end{tabular}

Correlation Analysis. Using regression analysis method to study the problem, we must first consider the explanatory variables to the question of whether the existence of multi-collinearity[3]. In order to avoid multi-collinearity effect on the regression results, in multivariate linear regression, to test the correlation of variables. Before the correlation test, the independent variables were normalized to. The original data and the mean difference divided by the standard deviation. Under the table 2 , as the result of correlation analysis.

Table 2 correlation analysis

\begin{tabular}{|l|l|l|l|l|r|r|r|r|r|r|r|l|}
\hline $\mathrm{X}_{11}$ & & & & & & & & & & & 1.000 \\
\hline $\mathrm{X}_{10}$ & & & & & & & & & & & 1.000 & -0.262 \\
\hline $\mathrm{X}_{9}$ & & & & & & & & & & 1.000 & 0.144 & 0.161 \\
\hline $\mathrm{X}_{8}$ & & & & & & & & & 1.000 & 0.093 & 0.158 & 0.341 \\
\hline $\mathrm{X}_{7}$ & & & & & & & & 1.000 & 0.200 & -0.016 & -0.063 & 0.255 \\
\hline $\mathrm{X}_{6}$ & & & & & & & 1.000 & 0.399 & -0.195 & -0.167 & -0.118 & -0.337 \\
\hline $\mathrm{X}_{5}$ & & & & & & 1.000 & -0.332 & -0.176 & -0.168 & -0.053 & -0.170 & 0.257 \\
\hline $\mathrm{X}_{4}$ & & & & & 1.000 & -0.052 & 0.091 & 0.197 & 0.026 & -0.222 & 0.221 & -0.196 \\
\hline $\mathrm{X}_{3}$ & & & & 1.000 & 0.298 & -0.210 & 0.286 & -0.109 & -0.102 & -0.312 & 0.035 & -0.443 \\
\hline $\mathrm{X}_{2}$ & & & 1.000 & -0.510 & 0.078 & 0.263 & -0.506 & 0.144 & 0.256 & 0.254 & 0.191 & 0.395 \\
\hline $\mathrm{X}_{1}$ & & 1.000 & 0.177 & 0.107 & 0.409 & 0.083 & 0.186 & 0.417 & 0.162 & 0.234 & 0.260 & 0.096 \\
\hline $\mathrm{Y}$ & 1.000 & 0.352 & -0.295 & 0.833 & 0.284 & -0.071 & 0.398 & 0.132 & 0.098 & -0.221 & 0.191 & -0.292 \\
\hline & $\mathrm{Y}$ & $\mathrm{X}_{1}$ & $\mathrm{X}_{2}$ & $\mathrm{X}_{3}$ & $\mathrm{X}_{4}$ & $\mathrm{X}_{5}$ & $\mathrm{X}_{6}$ & $\mathrm{X}_{7}$ & $\mathrm{X}_{8}$ & $\mathrm{X}_{9}$ & $\mathrm{X}_{10}$ & $\mathrm{X}_{11}$ \\
\hline
\end{tabular}

In general, when the correlation coefficient between 0.6 to 0.8 , that is a strong correlation between 0.8 to 1 , is extremely strong. As can be seen from table 2 , the correlation coefficients between variables are relatively low, the vast majority of the correlation coefficients between variables in 0.3 , showed a weak correlation; only the correlation coefficient of X2 and X3, X1 and $\mathrm{X} 4$ correlation coefficient is higher, but only between 0.4 to 0.6 . So the correlation analysis conclusion is: the multi-collinearity among variables less likely.

Regression Analysis. Multiple regression analysis using EXCEL. 
Table 3 multiple regression analysis and detection

\begin{tabular}{|l|l|l|l|l|l|l|}
\hline \multicolumn{2}{|l|}{ regression statistics } & & & & & \\
\hline Multiple R & 0.9486 & & & & & \\
\hline R Square & 0.8999 & & & & & \\
\hline Adjusted R Square & 0.8387 & & & & & \\
\hline standard error & 0.4177 & & & & & \\
\hline observed value & 30.0000 & & & & & \\
\hline & & & & & & \\
\hline & Coefficients & standard & t Stat & P-value & Lower & Upper \\
\hline Intercept & -4.1950 & 1.5126 & -2.7734 & 0.0125 & -7.3729 & -1.0172 \\
\hline X Variable 1 & 0.4799 & 0.1825 & 1.8376 & 0.6669 & -0.3036 & 0.4633 \\
\hline X Variable 2 & 0.5090 & 0.3202 & 1.5898 & 0.1293 & -0.1636 & 1.1816 \\
\hline X Variable 3 & 4.6442 & 0.5010 & 9.2692 & 0.0000 & 3.5916 & 5.6969 \\
\hline X Variable 4 & -0.6204 & 0.5587 & -1.1105 & 0.2814 & -1.7941 & 0.5533 \\
\hline X Variable 5 & 0.7760 & 0.2833 & 2.7387 & 0.0135 & 0.1807 & 1.3712 \\
\hline X Variable 6 & 0.4991 & 0.7130 & 0.7000 & 0.4929 & -0.9989 & 1.9972 \\
\hline X Variable 7 & 2.0001 & 0.6635 & 3.0143 & 0.0074 & 0.6061 & 3.3942 \\
\hline X Variable 8 & 0.6718 & 0.3133 & 2.1446 & 0.0459 & 0.0137 & 1.3299 \\
\hline X Variable 9 & 0.0269 & 0.1891 & 0.1422 & 0.8885 & -0.3705 & 0.4243 \\
\hline X Variable 10 & 0.4285 & 0.1879 & 2.2810 & 0.0349 & 0.0338 & 0.8232 \\
\hline X Variable 11 & 0.1281 & 0.2421 & 0.5290 & 0.6032 & -0.3805 & 0.6366 \\
\hline & & & & & & \\
\hline
\end{tabular}

$\mathrm{EDI}=-4.1950+0.4799 \mathrm{X}^{1}+0.5090 \mathrm{X}^{2}+4.6442 \mathrm{X}^{3}-0.6204 \mathrm{X}^{4}+0.7760 \mathrm{X}^{5}+0.4991 \mathrm{X}^{6}$

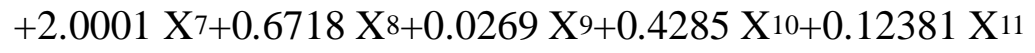

\section{Multivariate Linear Regression Model Test}

Multiple Linear Regression Fit. In the multivariate linear regression model, in order to illustrate the estimation model of fitting degree of observation value, can use multiple coefficient of determination to $" \mathrm{R}^{2 n}$. The multiple coefficient of determination is between 0 and 1 between a

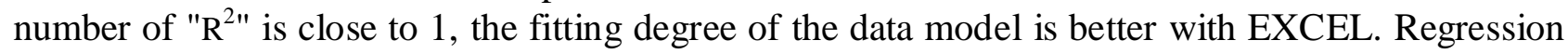
analysis, calculation of the coefficient of determination of the multiple coefficient of determination and correction of the results can be directly obtained. The model of multiple coefficient of determination and correction coefficient of determination were 0.8999 and 0.8387 . the higher fitting degree of the data model.

The Significance Test of Regression Parameters (t test). When EXCEL is used for regression analysis, the $t$ statistic corresponding to the estimated parameters has been given. Take a $=0.10$, check the $\mathrm{t}$ distribution table can be obtained $\mathrm{t}_{-}(\mathrm{a} / 2)(\mathrm{n}-\mathrm{k})=\mathrm{t}_{0.05}(30-12)=1.7341$, Statistics and comparison shows that the calculation of $\mathrm{t}_{1}, \mathrm{X}_{3}, \mathrm{X}_{5}, \mathrm{X}_{6}, \mathrm{X}_{8}, \mathrm{t}$ statistic corresponding $\mathrm{X}_{10}$ is greater than the critical value of 1.7341, indicating that the size of the company, the company's capital structure, the proportion of independent directors, the proportion of tradable shares, investment in environmental protection of the government, the state-owned holding respectively have significant effect on corporate environmental information the disclosure, the remaining variables did not pass the significant test. 


\section{Conclusion}

From the analysis, the large-scale state-owned enterprise environmental information disclosure and the relatively high level of enthusiasm, so as to establish a good corporate image, to obtain social and government support; government subsidies and incentives to enterprises and environmental protection, can promote the enterprise environmental information disclosure quality; heavily indebted companies, in order to obtain the trust investors and external support, will be willing to disclose more environmental information; the independence of the board of directors is stronger, the enthusiasm of enterprise environmental information disclosure is strong. Therefore, as long as the government to strengthen the control and support of corporate environmental information.

\section{References}

[1] Z.R. Wang: Research on the influencing factors of enterprise environmental information disclosure level(MS.,Ningbo University,China,2104),P.30.(In Chinese)

[2] X. Zhao: Study on the influencing factors of environmental information disclosure(MS.,Hubei University of Technology,China,2104),P.25.(In Chinese)

[3] B. Chen: Effects of corporate environmental information disclosure in the perspective of ecological economy(MS.,Hunan Normal University, China,2012),P.28.(In Chinese)

[4] H.T. Shen and J. Feng: Accounting Research, Vol.21 (2012) No 2,P.72-78.(In Chinese) 